\title{
OCCURRENCE OF SOME PREDACEOUS MITES ASSOCIATED WITH PLANTS FREE FROM CHEMICAL PESTICIDES
}

\author{
METWALLY, A. M. ${ }^{1}$, HANAA M. EL KHATEEB ${ }^{2}$ and A. S. SANAD ${ }^{2}$ \\ 1. Fac. of Agric., Al-Azhar University, Cairo, Egypt. \\ 2. Dep. of Acarology - Plant Protection Research Institute, ARC, Dokki Giza.
}

(Manuscript received 25 February 2013)

\begin{abstract}
Occurrence of some predacious mites associated with plants free from chemical pesticides were conducted, Six mite species belong to the family Phytoseiidae and two mite species of the family Ascidae were recorded. The plants belong to 11 families most of which were weeds. Amblyseius swirskii Athias-Henriot was the most commonest and abundant mite species in this study followed by Euseius scutalis (Athias-Henriot). The family Poaceae was the gainful one of the 11 host plant families, followed by the family Solanaceae in herbouring predaceous mite species.
\end{abstract}

\section{INTRODUCTION}

Occurrence of bio-agents in specific regions are essential task, as it can show the status of the bio-agent/pests interactions, rising of new species or decline of dominant ones and the recovery of such fauna component after exposure to pesticides application. This action considers the first step to further studies about the use of bio-agents in biological control.

Phytoseiid mites (Phytoseiidae: Mesostigmata) are predators of phytophagous mites and insects. Some species also feed on pollen and exudates from plants, but rarely plant tissue. Several members of this family are of great importance in the biological control of spider mites and other insect pests annoying crop production.

Many researches dealt with the occurrence of phytoseiid mites in Egypt ( ElHalawany et. al. (1990), Abo-Shnaf, (2005), Ali (2006) and Azouz et. al. (2011) fruit trees\}, Basha et. al. 2001 \{vegetables\} Hagrass et. al. (2008) \{field crops\}, Romeih et. al. (2010)\{ aromatic and medical plants\}, Heikal and Fawzy, (1998), Abd El-Halim and Rahil (1999), El-Adawy et. al. (2001) and Metwally and Sanad (2005) fnoncultivated plants\}.

The intensive use of chemical insecticides in the agriculture production (mainly in pests control) numbers and species of natural enemies has diminished in cultivated plants. This work aimed to through highlights the roll of plants free from pesticides as a natural source or alternative safe shelters of some predacious mites during the stiff conditions. 


\section{MATERIALS AND METHODS}

\section{Occurrence and taxonomical studies}

Observations were conducted on 22 plants free from pesticides belonging to 11 families. These were mainly weeds, vegetables and fruit trees (Table 1). The area of study covered the indicated plants in Qalyobia, Beheira and Ismailia governorates. The study was conducted during the period 2008 to 2009. Random samples of leaves and flowers were collected. Leaf samples were examined in the laboratory directly under the stereomicroscope, while other samples were placed in modified Tullgren funnel. The collected mites were mounted in Hoyer's medium, and examined.

\section{RESULTS AND DISCUSSION}

Results presented in Table (1) included predaceous mite species existence at plant parts. Identified mites were six species belonging to the family Phytoseiidae and two species to the family Ascidae. Table (2) showed the distribution of the mite species and the number of plants. Results revealed that Amblyseius swirskii AthiasHenriot, was the most common and abundant species followed by Euseius scutalis (Athias-Henriot), Typhlodromus negevi (Swirski and Amitai) and T. athiasae Porath and Swirski. Plants in relation to harbouring predatory mite species were arranged in Table (3). Arundo donax L. harboured four mite species followed by Convolvulus arvensis $\mathrm{L}$. and Vitis vinifera $\mathrm{L}$. which gained three mite species. The abundance among obtained predaceous mite genera was illustrated in Fig. (1). Maximum presence was genus Amblyseius followed by Neoseiulus and Typhlodromus. Sorting host plant families harboring predaceous mite species were illustrated in Fig. (2). Family Poaceae was the gainful one followed by Solanaceae and Amaranthaceae.

Results in Table (1) showed the importance of plants free from pesticides as a source or save shelters for bio-agents. The results agreed with those obtained by Heikal and Fawzy (1998) who stated that mulberry trees acts as a natural source of two native phytoseiid mites ( $A$. swirskii and E. scutalis). Also Abdel Halim and Rahil (1999) represented 11 species of phytoseiid mites ( E. scutalis, Typhlodromus schusteri Yousef and El-Brollosy, T. athiasae, Phytoseius finitimus Ribaga, Paratyphlodromus reticulatus Yousef and El-Brollosy, Amblyseius mumae Shehata and Zaher, A. badryi Yousef and El-Brollosy, Amblyseius cucumeris Oudemans, Amblyseius zaheri Yousef and El-Brollosy, Amblyseius cydnodactylon Shehata and Zaher and Amblyseius longispinosus Evans, inhabiting apricot trees and surrounding Bermuda grasses. El-Adway et. al. (2001) showed the role of the castor plants Ricinus communis L., as a source of the bio-agents Stethorus gilvifrons, Scolothrips longicornis, Orius spp. and Amblyseius spp. 
The role of cover crops to enhance Euseius tulearensis (Blommers) on leguminous in citrus orchards was demonstrated by Grafton-Cardwell et. al. (1999). Papaioannou-Souliotis et. al. (2000) presented the role of weeds and hedges as ecological refuges and sources of the most abundant and most economically important phytoseiid species Euseius finlandicus (Oudemans), Typhlodromus pyri Scheuten and Amblyseius andersoni Chant, on apple in Central Greece. Kreiter et. al. (2005) surveyed the mites on some perennial crops and the surrounding wild vegetation, mainly in date palm production areas, twelve species, among them 4 were new for Tunisian fauna with one new genus Africoseiulella and one new species $A$. flechtmanni. In regular mite collections made on different host plant species in various localities of Hungary, Ripka et. al. (2005) reported that 113 mite species, out of them, Neoseiulus setulus Fox, Typhlodromus (Anthoseius) cryptus Athias-Henriot, Typhlodromus (Anthoseius) georgicus Wainstein, Typhlodromus (Anthoseius) kazachstanicus Wainstein were new for the Hungarian fauna.

Also, it can be concluded that such kind of periodical and steady regional surveys lead to enriching the taxonomic data. Such data contributes to expanding the knowledge base of the contents of the local environment. This progressing knowledge is the corner stone to prospective researches. 
Table. 2. Relation between predatory mite species and number of plants

\begin{tabular}{|l|c|}
\hline \multicolumn{1}{|c|}{ Mite species } & No. hosts \\
\hline A. swirskii & 22 \\
\hline T. negevi & 5 \\
\hline E. scutalis & 4 \\
\hline N. barkeri & 3 \\
\hline L. lindquisti & 2 \\
\hline T. athiasae & 2 \\
\hline N. arundonaxi & 1 \\
\hline P. pygmaeus & 1 \\
\hline
\end{tabular}

Table. 3. Relation between plants and predaceous mite species numbers

\begin{tabular}{|l|c|l|c|l|c|}
\hline \multicolumn{1}{|c|}{ Plant } & $\begin{array}{l}\text { No. } \\
\text { mites }\end{array}$ & \multicolumn{1}{|c|}{ Plant } & $\begin{array}{l}\text { No. } \\
\text { mites }\end{array}$ & \multicolumn{1}{|c|}{ Plant } & $\begin{array}{l}\text { No. } \\
\text { mites }\end{array}$ \\
\hline A. sylvesris & 4 & L. aegyptiaca & 2 & C. dactyon & 1 \\
\hline A. donax & 4 & M. nigra & 2 & C. longus & 1 \\
\hline C. arvensis & 3 & P. guajava & 2 & D. sanguinalis & 1 \\
\hline C. alopecuroides & 3 & S. glauca & 2 & E. crus-galli & 1 \\
\hline S. nigrum & 3 & S. melongena & 2 & H. syriacus & 1 \\
\hline V. vinifera & 3 & A. viridis & 1 & S. lycopersicum & 1 \\
\hline C. annuum & 2 & C. pamilum & 1 & & \\
\hline D. retroflexa & 2 & C. dioscoridis & 1 & & \\
\hline
\end{tabular}




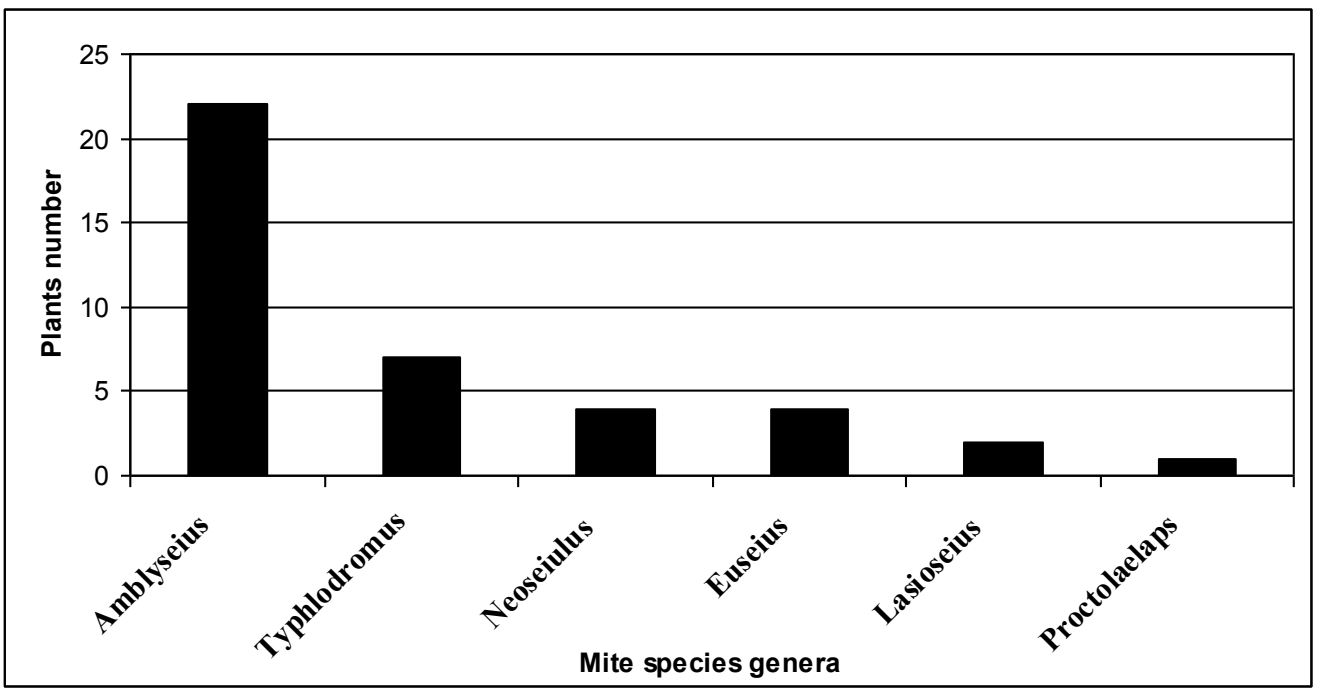

Fig. 1. Relation between predaceous genera and plants number.

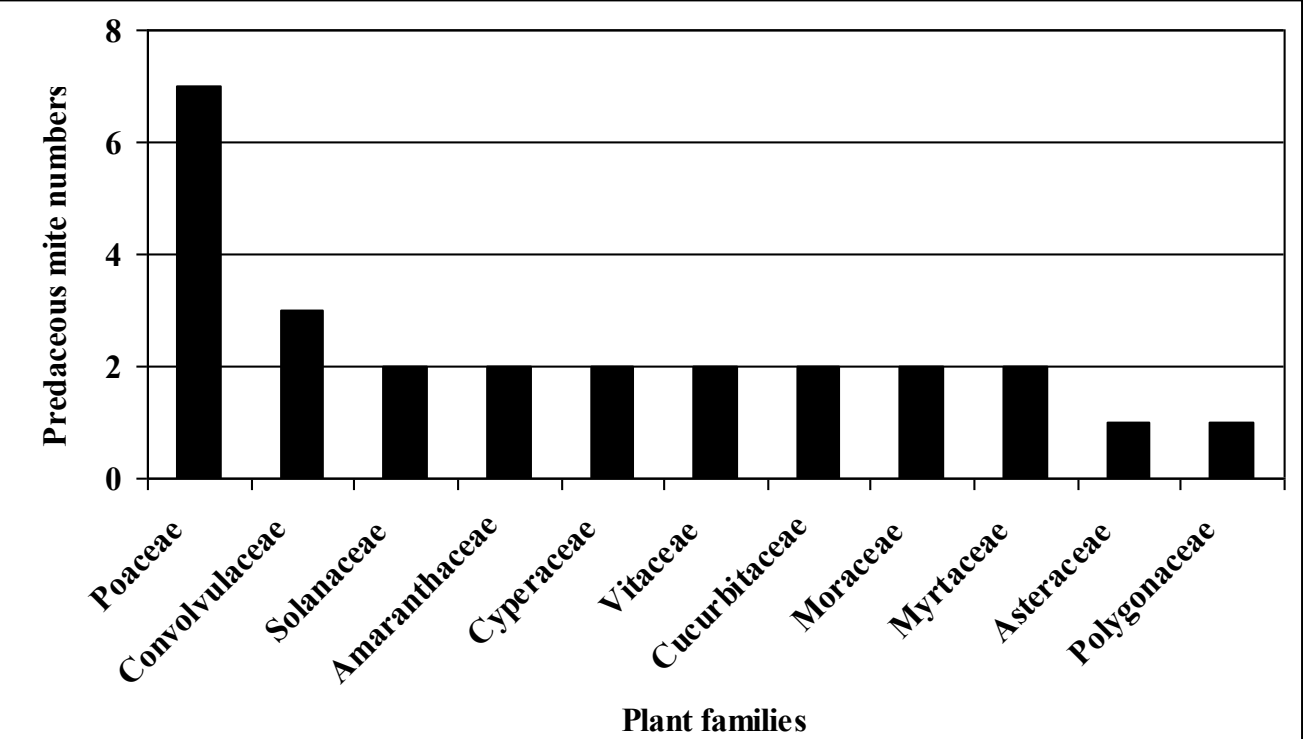

Fig. 2. Relation between plant family and predaceous mite species numbers. 


\section{REFERENCES}

1. Abd El-Halim S. M. and A. A. R. Rahil. 1999. Mites inhabiting apricot trees and its associate weeds, bermuda grass, at Fayoum governorate. Ann. Agric. Sci. Moshtohor, 37(3): 1987-1998.

2. Abo-Shnaf, R. A. 2005. Studies on some aerial and soil mites inhabiting fruit trees in Fayoum Governorate. M. Sc. Thesis, Fac. Agric. Cairo Univ., 164 pp

3. Ali, M. 2006. Studies on some mite species infesting deciduous fruits in Upper Egypt. Ph. D. thesis Fac. Agric. Assiut Univ., 151 pp.

4. Azouz, H., A. Khalil and A. E. Abu Zaid. 2011. Survey of some mites and spiders associated with date palm at Beni-Suef governorate, Egypt. Egypt. J. of Appl. Sci., 26: 50- 63.

5. Basha A. E., A. A. Yousef, M. H. Ibrahem and E. M. Mostafa. 2001. Five new phytoseiids from Egypt (Acari: Gamasida: Phytoseiidae). Al-Azhar J. Agric. Res., 33: 371- 386.

6. El-Adawy, A. M., N. M. Abdel-Gawad and T. A. El-Sharkawy. 2001. Castor bean, Ricinus communis, a promising source of mite's predators. Egypt. J. of Agric. Res. 79: 149-160.

7. El-Halawany, M. E., G. A. Ibrahim and M.A. Abdel-Samad. 1990. Mites inhabiting fig varieties. Agric. Res. Rev., 68: 39 - 48.

8. Grafton-Cardwell, E., Y. Ouyang and L. Bugg. 1999. Leguminous cover crops to enhance population development of Euseius tulearensis (Acari: Phytoseiidae) in Citrus. Biol. Cont. 16: 73-80.

9. Hagrass, A. E., M. E. EL-Naggar, A. M. EL-Naggar and W. M. Abou-Zeid. 2008. incidence of mites inhabiting some field crops in two localities at Dakahlia Governorate. Egypt. J. Agric. Res. 86: 353- 366.

10. Heikal, H. I. and M. M. Fawzy. 1998. Mulberry trees as a good source of the predatory mites, Euseius scutalis, or Amblyseius swirskii (Acari: Phytoseiidae). Egypt. J. Biol. Cont., 8: 77- 84.

11. Kreiter, S., M. S. Tixier, P. Auger and K. L. Grissa. 2005. Phytoseiid mites (Acari: Mesostigmata) of Southern Tunisia. Acarologia. 46: 5-13.

12. Metwally A. M. and A.S. Sanad. 2005. Description of the immature and adult stages of Neoseiulus arundonaxi n.sp. (Acari: Phytoseiidae) from Egypt. (Bull. Ent. Soc. Egypt, 82,2005 (63-70). 
13. Papaioannou-Souliotis, P., D. Markoyiannaki-Printziou and G. Zeginis. 2000. Observations on acarofauna in four apple orchards of Central Greece. II. Green cover and hedges as potential sources of phytoseiid mites (Acari: Phytoseiidae). Acarologia. 41: 411-421.

14. Ripka, G., A. Fain, A. Kazmierski, S. Kreiter and W. Magowski. 2005. New data to the knowledge of the mite fauna of Hungary (Acari: Mesostigmata, Prostigmata and Astigmata). Acta phyto. Entomal. Hung. 40: 159-176.

15. Romeih, M. A., M. Hassan, M. A. Rizk and R. A. Abo-Shnaf. 2010. Egyptian checklist of mites from aromatic, medicinal and ornamental plants. Acarines, 4: 37- 46. 


\section{تواجد بعض الأكاروسات المفترسة علي النباتات غير المعاملة بالمبيدات الكيماوية}

عبد الستار محمد متولي' هناء محمد الخطيب † ، أحمد سعيد سند ‘

$$
\text { r. r. كلبة الزراعة جامعة الأزهر }
$$

تمــت دراســة تواجد بعض المفترسـات الأكاروسـية علـي بعض النباتـات غيـر

المعاملـة بالمبيدات. حيـث تم تسـجيل سـنة انواع تابعـة لفصبلة Phytoseiidae ونـوعين تابعين لفصيلة Ascidae. تتنمي النباتات (اغلبها حشـائش) الي $1($ فصيلة نباتية. وكان المفترس الأكاروسي Amblyseius swirskii Athias-Henriot هو الاكثر تواجدا بين الانواع التي تم دراستها، يليه النوع Euseius scutalis (Athias-Henriot) ـ الفصيلة النجيلية كانت هي اكثر العوائل النباتية احتواءا للمفترسات يليها الفصيلة الباذنجانية. 
